\title{
Study on the Cultivation of College Students' Employment Ability Under the Mode of the University-Enterprise Cooperation in Local Colleges and Universities
}

\author{
Qinghong QU ${ }^{1, a, *}$, Shu LIU ${ }^{2, b}$ \\ ${ }^{1}$ Media College, Baicheng Normal University, Baicheng 137000, China \\ ${ }^{2}$ College of Mechanical Engineering, Baicheng Normal University, Baicheng 137000, China \\ aemail:quqinghong@163.com, bemail:dimnet@163.com, "corresponding author
}

Keywords: Local Colleges and Universities, University-Enterprise Cooperation, Employment Ability

\begin{abstract}
Along with the popularization and internationalization process of higher education, a new phenomenon has emerged that local colleges and enterprises are becoming more and more closely related, as well as they train vast professional talents through the mode of the university-enterprise cooperation in order to explore better development model in the future for improving their competitiveness and meeting the needs and development of the times. Through the university-enterprise cooperation, local colleges and universities can strengthen students' professional ability training to improve the local college students' employment ability according to the needs of enterprises, perfect employment service system of the schools and explore the best development path.
\end{abstract}

\section{Introduction}

With the rapid development of social economy, the education system of local colleges and universities have carried through corresponding reforms, and the employment problem of college students have attracted more and more attention from the society. At present, there is a common problem in local colleges and universities at home that higher education does not combine theory with practice effectively which has seriously hampered our country's students employment ability. In view of this situation, all local colleges and universities have begun to pay attention to the cultivation of students' practical ability and the practice teaching of teachers. This article aims at exploring the strategies of college students' employment ability training and constantly improving the level of practice teaching and students' practical ability in local colleges and universities for effectively improving the local college students employment rate based on the mode of the university-enterprise cooperation

\section{The Main Mode of Cooperation between Local Colleges and Enterprises in Our Country at Present}

The Teaching and Scientific Research Achievements of Local Colleges and Universities are Generally Market-Oriented. Local colleges and universities sign a contract for the transfer with enterprises to achieve market-oriented of the teaching and scientific research achievements through the technology exchange and trade fair and various forms, at the same time the enterprise can make scientific research achievements which have been purchased into goods in the market to promote.

School-Run Factory. School-run factory is a special kind of university-enterprise cooperation mode and is science and technology industries which are found by their own university, for example, Tsinghua Unisplendour and Peking University Founder. In this kind of school-run factory, the science-and-technology enterprises have obvious advantages and can provides many financial support for the school and the state.

Universities and Enterprises Sign a Long-Term Cooperation Agreement. Through the signing the long-term comprehensive cooperation agreement, local colleges and universities and enterprises will carry out a long-term cooperation in employment of graduates, scientific research, 
professional settings, experimental practice and so on. Some teaching-oriented undergraduate colleges and universities are exploring cooperation matters with enterprises in order to make talent training more pragmatic and efficient and make the graduates quickly adapt to the enterprise, which requires close cooperation between schools and enterprises.

\section{The Problems Existing in the Cooperation between Local Colleges and Enterprises}

Policies and Regulations Introduced by Government are not Perfect. Government can't provide strong support in the aspects of funding and policy which resulting in university-enterprise cooperation lacks the corresponding basis. Although the country has formulated relevant laws to support cooperation between school and enterprise, legal protection measures is inadequate, and some local governments only treat university-enterprise cooperation in oral and do not introduce corresponding system, monitoring, security, legal and other aspects of the policy. Therefore, university-enterprise cooperation between local colleges and universities and enterprises exist many bad phenomena, for example the government is in a high voice, safeguard measures lag behind and stimulus policies of tax laws and regulations are lack, which seriously influence the policy of university-enterprise cooperation to be carried out.

The University Teachers do not Have Proper Thought and Awareness for University-Enterprise Cooperation. In college, some teachers think that universities should be a paradise of pure spirit where students can look forward to the ideal and realize their own dreams, and once the excessive pursuit of employment rate, the implement of university-enterprise cooperation is easy to make college Students fall into the situation of prematurity professional training. University is the place of the pursuit of the spirit, or the spirit will collapse, but the spirit and material is a pair of complementary unity, when in the pursuit of pure spirit and pure academic, we should pay more attention to whereabouts of graduates, and after all, the students would live and develop in society using the knowledge and skills that are learned in the university. Therefore, there exist a contradictory between university-enterprise cooperation and academic and spiritual edification in colleges and universities, which can be in mutual promotion and common development so that the colleges and universities become more attractive in the society and can cultivate more talents for the social needs.

The Domestic Enterprises do not Have Proper Thought and Awareness for University-Enterprise Cooperation. In terms of enterprises, due to the current imbalance between the supply and demand of labor, the most common situation is graduates seeking to use the unit, rather than the employer for graduates. Once graduates can be employed by the enterprises, they often think that the enterprise is the protection of their own lives, rather than thinking about how to create more economic benefits for the enterprise. Enterprises are also not aware of the important role of high-quality technical graduates for themselves. As everyone knows, if there is no adequate human capital, most enterprises can only feel powerless, frustrated and helpless. This situation leads to many enterprises do not want to take money out to participate in the training of human resources, enterprises pay more close attention to human resource demand and are not interested in the long term and university-enterprise cooperation.

The Depth of University-Enterprise Cooperation is Insufficient, Form and Content is not Much. Currently university-enterprise cooperation in terms of content lack in depth, the most of cooperation forms are mostly limited to the establishment of school enterprise cooperation laboratory and external training practice base. Enterprises often arrange the practice link with economic interests as the core, which affects the quality and effect of teaching. In order to strengthen practice teaching link, colleges and universities arrange practice training for the students that is not closely related to the university knowledge. The practice training only make the students become a simple labor force which makes a lot of students lose their interest in learning.

The Lack of Teaching Management Measures in Colleges and Universities. At present, the modes of university-enterprise cooperation do not match with requirements of enterprises in training, professional setting, curriculum development and other aspects. The teaching modes in colleges mostly adopt traditional and subject-oriented manner which affects the development of 
university-enterprise cooperation. Talents training in local colleges and universities mainly pursue systematic and integrity of professional theory, and lack of targeted and targeted training, so that the promotion of university-enterprise cooperation has produced some difficulties. At the same time, there is a certain difficulty in the evaluation of the effect university-enterprise cooperation and credit identification for students taking part in university-enterprise cooperation, which is also an important reason for the deepening university-enterprise cooperation.

\section{The Concrete Strategy of College Students' Employment Ability Training under the Mode of University-Enterprise Cooperation}

Construction of Zero Distance Training Mode. According to the needs of the local market, local colleges and universities should promote the education reform, colleges and universities should implement "zero distance" training mode in the teaching and practice link and so on, and truly realize integration and cooperation of colleges and businesses in teaching, practice, students employment and other aspects for building a "zero distance" of mode of university-enterprise cooperation. Local colleges and universities and enterprises should build a efficient system of teaching and practice through the integration of their respective advantages in resources in order to strengthen the cultivation of students' employment ability.

The Formation of Double-Professionally-Titled Teachers Team. The smooth implementation of the mode of university-enterprise cooperation requires local colleges and universities to set up a team of double-professionally-titled teachers. The formation of double-professionally-titled teachers team can be established from two aspects for local colleges and universities as well as enterprises, one hand local colleges and universities can select outstanding teachers to learn and practice professional skills in local enterprises or famous enterprises, which not only can improve the teachers' practical experience, but also improve the comprehensive quality of teachers; on the other hand enterprises also should select outstanding and capable employees to learning in colleges and universities, they can timely carry out the exchange of experience or personal speech and teach their practical experience to students of the local colleges and universities. Through the "two-way" learning mode, local colleges and universities and enterprises can learn from each other and jointly enhancing together.

The Implementation of Integration Teaching of Theory and Practice. The smooth implementation of integration teaching of theory and practice needs local colleges and universities to change the traditional teaching ideas and mode, teachers in the teaching process should try to combine theory with practice. First, according to local market demands, local colleges and universities should make changes and adjustments in the professional training timely. Second, in the curriculum setting, local colleges and universities should pay special attention to the proportion among the professional course, practice course and the public class, and strongly highlight practical teaching and practical application of teaching. Finally, local colleges and universities should keep pace with the times and constantly reform in the teachers' teaching methods and techniques combined with the characteristics of professional courses, and make further efforts to improve the teaching practice and enhance students' employment skills which is very necessary for graduates.

\section{Summary}

The successful employment of college students, mainly depends on whether graduates have technical expertise required for the enterprise. At present, the local colleges and universities improve the employability of college students through university-enterprise cooperation and have obtained certain result. Government, society, colleges and universities should pay attention to attach great importance to the cultivation of students' employment ability. Based on the basis of university-enterprise cooperation, students can participate in the development process of new products and the actual operation of the enterprises, and in this process of mutual cooperation students' practical ability has been improved, but also accumulated a wealth of practical experience which lays the foundation for the college graduates. 


\section{References}

[1] Zhun Xie. The promotion of college students' employment ability based on the mode of university-enterprise cooperation[J], Economic and Trade Practice,2015.

[2]Feng Jin, Huaming Jiang, Yan Cui. Research on the training mode of college students' employment ability based on the second class taking with the aid of university-enterprise cooperation to carry out professional practice[J], Knowledge Guide,2015. 